\title{
85th anniversary of Moscow State University of Technology "STANKIN"
}

In 2015, Moscow State University of Technology "STANKIN" celebrated the 85th anniversary of its foundation. It was created to assist in the development of the Soviet machine tool industry and to provide the requisite engineers and designers.

The basis of STANKIN University's vitality is its scientific personnel. Today, a whole series of scientific schools is active within the institution. Some are recognized as leaders in their field; others are relatively young but have already achieved significant results. They address specialties such as tool technology (under the direction of V.A. Grechishnikov); design and technological information sciences (under the direction of Yu.M. Solomentsev); metrology (under the direction of V.I. Teleshevskii); metal cutting machines (under the direction of V.V. Bushuev); the cutting of materials and coatings (under the direction of S.N. Grigoriev); and materials science (under the direction of L.S. Kremnev).

In recent years, the development of MSTU "STANKIN" has mainly been driven by its scientific activity, with a corresponding increase in its budget by more than 100\%. In the last years, revenue from scientific activity has quintupled. The financial support from research and development activities is the main source in the structure of the University's income and the effective tool for material and technical base development.

The main sources of research funding are contracts with industrial and scientific enterprises for the creation of particular products; federal funds under state contracts; and the university's own resources.

The main principles of scientific research at MSTU "STANKIN" are as follows:

- Integration of scientific and educational activity, so that the team working on scientific projects includes not only university educators but also students at different stages of their careers. In addition, the results of scientific activity are promptly introduced in the education process.

- Continuity, so that fundamental and exploratory research creates the basic principles and knowledge required for practical innovations that result in more competitive manufacturing products.

- Import substitution, so that domestic equipment and technology is developed to match the performance of imported systems, with a view to ensuring the independence of Russian manufacturing, especially in relation to dual use systems.

Today, the main goal of MSTU "STANKIN" is to provide the personnel and practical systems needed in order to upgrade the equipment used in Russian manufacturing and ensure its independence from foreign suppliers, especially in relation to national defense and the security of high technology systems: the defense industry, the aerospace industry, ship building, and power industry equipment.

The university's R\&D partners are the Russian Academy of Sciences and leading research institutes involved in the development and application of manufacturing systems within the jurisdiction of the Federal Space Agency and the Rostekhnologii and Rosatom state corporations.

In 2008, with the long-term goal of ensuring that Russian manufacturing (in particular, high technology components of the military-industrial complex) is independent and competitive, the administration of MSTU "STANKIN" set up a separate subdivision: the Federal Centre of Multiple-access (CKP) "State Engineering Centre" of MSTU "STANKIN". According to resolutions of the Government Commission on the Development of Industry, Technology, and Transportation, CKP MSTU "STANKIN" should be the primary organization ensuring the development of Russian machine tool design and the re-equipment of strategic branches of manufacturing with competitive import substituting systems.

Today in the structure of CKP MSTU "STANKIN" a number of international scientific and educational technological departments function successfully as the Russian-French Laboratory of Innovative Additive Technologies, the 
Russian-Italian Technology Training Center in the field of Mechanical Engineering and Metalwork, the Russian-Swiss Competence Centre in the field of Micromachining Technologies and Russian-Spanish Laboratory on Electrical Current Assisted Sintering Technologies.

In terms of the re-equipment of manufacturing enterprises, MSTU "STANKIN" performs the following functions.

- Methodological leadership to Russian universities, as the fundamental member of the consortium of educational institutions (270 universities in Russia and the Commonwealth of Independent States) focused on automated manufacturing.

- Development of analytical materials, regional strategies, state educational standards, and educational systems in relation to manufacturing and the production of manufacturing equipment (the machine tool and tool industry).

- Development and introduction of new education technologies in the light of fundamental international and national standards that reflect the best world trends in instructional technology and methods, educational management, and quality control.

MSTU "STANKIN" is carefully tracking world developments in manufacturing production and initiating research in those that seem most promising, within the following guidelines.

- Development of designs, software, and informational and methodological resources for the re-equipment of high technology manufacturing production.

- Creation of equipment and tools for manufacturing production (machine tools and other equipment for modifying structural materials, including tools; forging and pressing equipment; casting equipment; machining equipment; assembly and welding equipment; industrial robots; and other automatic systems).

- Creation of metrological equipment (such as measuring machines and instruments and computer systems for analysis of the results).

- The development of innovative manufacturing technologies (including technologies for flexible automated production).

- Creation of specialized information technology (software for the development of manufacturing production, planning, organization, technological preparations, and control of manufacturing production).

At present, MSTU "STANKIN" faces a set of problems whose solution will be critical to the institution's future and its ability to remain the leading Russian center devoted to the re-equipment and the independence of Russian manufacturing.

Educational challenges include improvement in the university's instructional process to meet the needs of Russian enterprises and their subdivisions specializing in the creation, introduction, and operation of systems for manufacturing production; and the development of the university's own creative potential.

Scientific challenges include continued and ever more effective research and design in fostering the university's development (introduction of unique equipment, enhancement of publication activities, protection and use of intellectual property, and international collaboration); and the creation of research subdivisions in innovative fields. Another goal is the creation of small enterprises to implement re-equipment projects and to introduce industrially the manufacturing production systems developed at STANKIN University.

Today, MSTU "STANKIN" is a leading scientific and educational center in the field of manufacturing technology. The University is:

- integrated scientific and educational structure, which seamlessly combines a network of scientific and production centers equipped with up-to-date equipment and infrastructure for high-quality professional training;

- distinguished scientific and pedagogic schools that not only produce graduates, postgraduates, and specialists, but also train scientific and pedagogical staff through their doctorate process;

- focused on the education of highly qualified specialists for manufacturing industries, with comprehensive incorporation of manufacturing innovations, information technologies, and economic competency.

As a result of progressive teaching methods and a highly skilled faculty, graduates from MSTU "STANKIN" represent the future technical elite of the country. Thanks to the administration's policy of integrating the university into the international educational community and cultivating relationships with institutions in France, Germany, Italy, Switzerland, Spain, Britain, China, India and the United States, graduates are in demand not only in Russia but abroad.

The special issue is devoted to the 85th anniversary of STANKIN University and completed with a wide range of the articles written by scientists of the University, which discover the main subjects and topics of the research work in MSTU "STANKIN". The represented advanced machining methods and techniques includes traditional and innovative technologies related to the cutting tools and mechanical engineering as milling of cutting tools' inserts from ceramics, their alloying, coating, hardening, development of ceramic-based composites for their production, study of the related electrical discharge machining, laser, plasma and electron beam treatments, modeling and diagnostics of related technological systems. The articles show current technological and scientific level of MSTU "STANKIN" and discover the main results of the important researching projects. 